\title{
Study on the Combustion Characteristics of Oil Shale and its Semicoke by Using a Thermobalance and a Drop-Tube Furnace
}

\author{
Li, Xiaoyang; Wang, Ze; He, Jingdong; Hao, Lifang; Li, Songgeng; Lin, Weigang
}

Published in:

Oil Shale

Link to article, DOI:

10.3176/oil.2019.2.02

Publication date:

2019

Document Version

Publisher's PDF, also known as Version of record

Link back to DTU Orbit

Citation (APA):

Li, X., Wang, Z., He, J., Hao, L., Li, S., \& Lin, W. (2019). Study on the Combustion Characteristics of Oil Shale and its Semicoke by Using a Thermobalance and a Drop-Tube Furnace. Oil Shale, 36(2), 271-284.

https://doi.org/10.3176/oil.2019.2.02

\section{General rights}

Copyright and moral rights for the publications made accessible in the public portal are retained by the authors and/or other copyright owners and it is a condition of accessing publications that users recognise and abide by the legal requirements associated with these rights.

- Users may download and print one copy of any publication from the public portal for the purpose of private study or research.

- You may not further distribute the material or use it for any profit-making activity or commercial gain

- You may freely distribute the URL identifying the publication in the public portal 


\title{
STUDY ON THE COMBUSTION CHARACTERISTICS OF OIL SHALE AND ITS SEMICOKE BY USING A THERMOBALANCE AND A DROP-TUBE FURNACE
}

\author{
XIAOYANG LI ${ }^{(\mathrm{a}, \mathrm{b})}, \mathrm{ZE} \mathrm{WANG}{ }^{(\mathrm{a}, \mathrm{b}) *}, \mathrm{JINGDONG} \mathrm{HE}^{(\mathrm{c})}$,

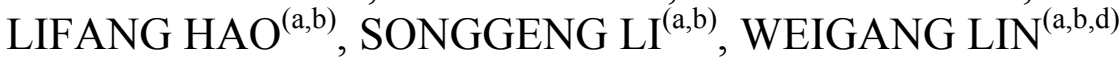

(a) State Key Laboratory of Multi-Phase Complex Systems, Institute of Process Engineering, Chinese Academy of Sciences, Beijing 100190, PR China

(b) University of Chinese Academy of Sciences, Beijing 100190, PR China

(c) Chinese Academy of Sciences, Beijing 100190, PR China

(d) Department of Chemical and Biochemical Engineering, Technical University of Denmark, 2800 Kgs. Lyngby, Denmark

\begin{abstract}
The combustion characteristics of Huadian oil shale and its semicoke are comparatively studied using a thermobalance (TB) and a drop-tube furnace (DTF). It is found that the ignition mechanism of oil shale and semicoke is hetero-homogeneous and heterogeneous, respectively. Drop-tube furnace experiments with both oil shale and semicoke show that the carbon $(C)$ conversion proceeds almost simultaneously with the particle burnout, while the hydrogen $(H)$ conversion is faster and that of nitrogen $(N)$ and sulphur (S) slower than the particle burnout. The kinetic behavior of semicoke combustion is analyzed by drop-tube furnace experiments based on the first-order reaction model, and the kinetic model with known pre-exponential factor $A_{a}$ $\left(26.3 \mathrm{~g} \cdot \mathrm{cm}^{-2} \mathrm{~s}^{-1} \cdot \mathrm{atm}^{-1}\right)$ and apparent active energy $E_{a}(65.8 \mathrm{~kJ} / \mathrm{mol})$ is obtained.
\end{abstract}

Keywords: oil shale characteristics, semicoke combustion kinetics, carbon conversion, emission of sulphur and nitrogen.

\section{Introduction}

Oil shale, as an unconventional oil source, is a sedimentary rock containing soluble bitumen and insoluble kerogen [1]. Oil shale is abundant in China with reserves of around $7.20 \times 10^{11}$ tons, which is equivalent to $4.76 \times 10^{10}$ tons of shale oil [2]. The Fushun retorting process as an industrialized oil shale pyrolysis technology with gas heat carrier is widely used in China [3]. In this process, a high amount of semicoke with low calorific value and high mineral content is generated as a by-product. The landfill of semicoke con-

\footnotetext{
${ }^{*}$ Corresponding author: e-mail wangze@ipe.ac.cn
} 
taining toxic chemicals such as polycyclic aromatic hydrocarbons and phenolic compounds is harmful to the environment [4]. Particularly, the leachates from semicoke are highly alkaline. Although the oil shale semicoke can be used in manufacturing bricks or cement [5], its total use in these areas accounts for only a small fraction of production every year [6].

In order to improve the comprehensive utilization of the oil shale resource on a large scale, combustion of semicoke is necessary [7]. Furthermore, for a downer pyrolysis technology coupled with a fluidized-bed combustor, semicoke is directly combusted in a fluidized bed for heat generation and the hot ash as solid heat carrier is mixed with oil shale in the downer [8]. Similarly, in the Enefit-280 process, pyrolysis takes place in a rotating kiln and semicoke is burnt in a circulating fluidized bed [9]. The combustion of semicoke for determining the ash temperature is critical to the whole system. Nevertheless, to achieve a highly efficient and clean combustion of semicoke is not an easy task because of its high contents of ash and sulphur. In general, the combustion of semicoke is of great importance in oil shale comprehensive utilization and worth studying more thoroughly.

So far, research on oil shale has been related mostly to pyrolysis, to maximize the yield of oil and improve its quality [10-12]. By contrast, studies of the characteristics of oil shale semicoke combustion accompanied by the emission of nitrogen $(\mathrm{N})$ and sulphur $(\mathrm{S})$ are rather scarce and have used mainly the thermogravimetric analyzer (TGA) method $[13,14]$. In this work, the combustion characteristics of oil shale and semicoke are comparatively studied using both TGA and drop-tube furnace (DTF) methods. Additionally, the emission behavior of nitrogen and sulphur, as well as the combustion kinetics of semicoke are investigated.

\section{Experiments}

\subsection{Samples}

The Huadian oil shale sample $(<6 \mathrm{~mm})$ is from Jilin Province of China. The sample of semicoke is prepared by pyrolysis at $500{ }^{\circ} \mathrm{C}$ for $30 \mathrm{~min}$ in $\mathrm{N}_{2}$ atmosphere $(200 \mathrm{ml} / \mathrm{min})$ by using a fixed-bed reactor. The oil shale and semicoke samples are both ground to powder $(<0.1 \mathrm{~mm})$ before experiments. The results of proximate and ultimate analysis of oil shale and semicoke are presented in Table 1.

Table 1. Proximate and ultimate analysis of oil shale and semicoke, $\%$

\begin{tabular}{|l|c|c|c|c|c|c|c|c|c|}
\hline & \multicolumn{3}{|c|}{ Proximate analysis } & \multicolumn{4}{c|}{ Ultimate analysis } & \multirow{2}{*}{$\mathrm{Q}_{\mathrm{d}, \mathrm{LHV}}$} \\
\cline { 2 - 9 } & $\mathrm{V}_{\mathrm{d}}$ & $\mathrm{A}_{\mathrm{d}}$ & $\mathrm{FC}_{\mathrm{d}}$ & $\mathrm{C}_{\mathrm{d}}$ & $\mathrm{H}_{\mathrm{d}}$ & $\mathrm{O}_{\mathrm{d}}$ & $\mathrm{N}_{\mathrm{d}}$ & $\mathrm{S}_{\mathrm{d}}$ & \\
\cline { 2 - 10 } Oil shale & 29.64 & 63.92 & 6.44 & 23.93 & 3.18 & 7.16 & 0.69 & 1.12 & 13.23 \\
Semicoke & 8.93 & 82.17 & 8.90 & 12.93 & 0.62 & 2.63 & 0.64 & 1.01 & 4.60 \\
\hline
\end{tabular}

$\mathrm{d}$ - dry weight basis; LHV $^{-}$lower heating value. 


\subsection{Thermogravimetry analysis}

The combustion tests are first conducted using the Netzsch STA 449 TGA. In each run, the sample of oil shale or semicoke (around $10 \mathrm{mg}$ ) is placed in a copple and heated from 30 to $900{ }^{\circ} \mathrm{C}$ at $20{ }^{\circ} \mathrm{C} / \mathrm{min}$ in air atmosphere $(50 \mathrm{ml} / \mathrm{min})$. Besides combustion, the pyrolysis of oil shale and semicoke is also tested by the TGA method for ignition analysis. The conditions for pyrolysis are similar to those for combustion but for $\mathrm{N}_{2}$ atmosphere. The weight loss and the reaction heat are recorded simultaneously. According to the combustion profile, the ignition temperature $\left(T_{\mathrm{i}}\right)$ [15], the temperature $\left(T_{\max }\right)$ at which the weight loss rate is maximum, and the burnout temperature $\left(T_{\mathrm{b}}\right)$ at which the weight loss rate is $0.5 \% / \mathrm{min}[16]$ are obtained.

\subsection{Drop-tube furnace experiments}

The schematic diagram of the experimental electric-heating DTF system is shown in Figure 1. The equipment is composed of an air preheater, a screw feeder with a stream of air as carrier, an alundum combustion tube $(90 \mathrm{~cm}$ height, $5 \mathrm{~cm}$ inner diameter), a sampling probe and a flue gas analyzer. The flow rates of the carrier gas and the preheated air are $1 \mathrm{~L} / \mathrm{min}$ and $5.8 \mathrm{~L} / \mathrm{min}$ (at room temperature), respectively. After preheating, the air temperature may reach $520{ }^{\circ} \mathrm{C}$. The feed rates of oil shale and semicoke are $0.25 \mathrm{~g} / \mathrm{min}$ and $0.12 \mathrm{~g} / \mathrm{min}$, respectively. The probe for sampling is fast cooled by a stream of $\mathrm{N}_{2}(1000 \mathrm{ml} / \mathrm{min})$ and water in a jacket to prevent combustion inside the probe. During the experiment, the sampling probe is moved along

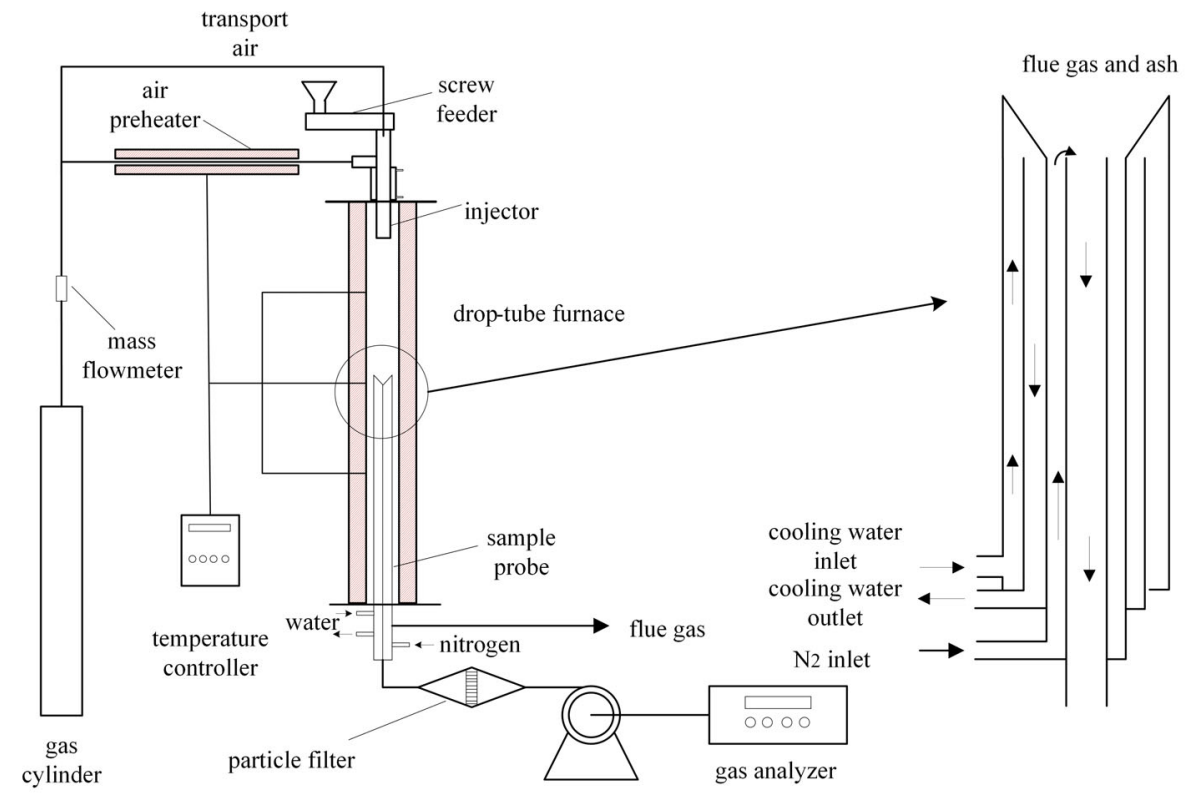

Fig. 1. Schematic diagram of the experimental electric-heating DTF system. 
the combustion tube to obtain solid and gas samples at different positions. The solid particles are isolated from the flue gas by filtration, and the flue gas is further introduced into the ABB EL3020 analyzer for composition analysis $\left(\mathrm{CO}, \mathrm{CO}_{2}, \mathrm{O}_{2}, \mathrm{~N}_{2} \mathrm{O}, \mathrm{NO}, \mathrm{SO}_{2}\right)$. The sampling at each position lasts for $15 \mathrm{~min}$. The ultimate analysis of solid particles over the filter is performed using the Vario MACRO cube element analyzer. The proximate analysis is conducted through a TGA rather than a conventional muffle furnace due to the limited amount of the solid particles sample. The running conditions are as follows: the semicoke sample (about $10 \mathrm{mg}$ ) is heated from 30 to $105^{\circ} \mathrm{C}$ at $20^{\circ} \mathrm{C} / \mathrm{min}$ in $\mathrm{N}_{2}$ atmosphere $(50 \mathrm{ml} / \mathrm{min})$, and kept at $105^{\circ} \mathrm{C}$ for $5 \mathrm{~min}$; the $\mathrm{N}_{2}$ flow is then switched to air $(50 \mathrm{ml} / \mathrm{min})$ and the sample is further heated from 105 to $850{ }^{\circ} \mathrm{C}$ [17].

The combustion efficiency is obtained on the basis of particle burnout and conversions of elements, according to the standard ash tracer method (ash is inert during combustion). The particle burnout is calculated by Equation (1):

$$
B=\left(1-A_{0} / A_{t}\right) /\left(1-A_{0}\right),
$$

where $B$ is the particle burnout, $A_{0}$ is the ash content of solid fuel before combustion, and $A_{t}$ is the ash content of solid residue over the filter in the probing system.

The conversion of $\mathrm{C}, \mathrm{H}, \mathrm{N}$ and $\mathrm{S}$ is calculated by Equation (2):

$$
\text { Con }=1-\left(W_{i t} / W_{i 0} \times A_{0} / A_{t}\right),
$$

where $W_{i 0}$ is the original weight percentage of an element in solid fuel before combustion, and $W_{i t}$ is the weight percentage of the element remained in the solid residue over the filter.

\section{Results and discussion}

\subsection{Characteristic temperatures}

The weight loss, differential thermogravimetry (DTG) and differential scanning calorimetry (DSC) curves from combustion and pyrolysis of oil shale and semicoke are shown in Figure 2. It can be seen that the combustion processes of both can be similarly divided into three stages. The first stage (below $200{ }^{\circ} \mathrm{C}$ ) is attributable to the release of moisture. The second stage $\left(200-550^{\circ} \mathrm{C}\right)$ is mainly related to the combustion of volatiles and fixed carbon. Accordingly, there appears a distinct exothermic peak in the DSC profile. The third stage $\left(660-760^{\circ} \mathrm{C}\right)$ is assignable to the decomposition of carbonates in inorganic minerals of endothermic character. It is noticeable that in the second stage of oil shale combustion there are two weight loss peaks, but only one peak for combustion of semicoke. The two peaks of 
exothermic character indicate the combustion of volatiles and of fixed carbon, respectively.

The characteristic temperatures of combustion of oil shale and semicoke are presented in Table 2. The table reveals that the ignition temperature of semicoke is higher than that of oil shale due to the lower volatile content of the former, while the higher burnout temperature of semicoke is indicative of its lower reactivity compared to oil shale's.
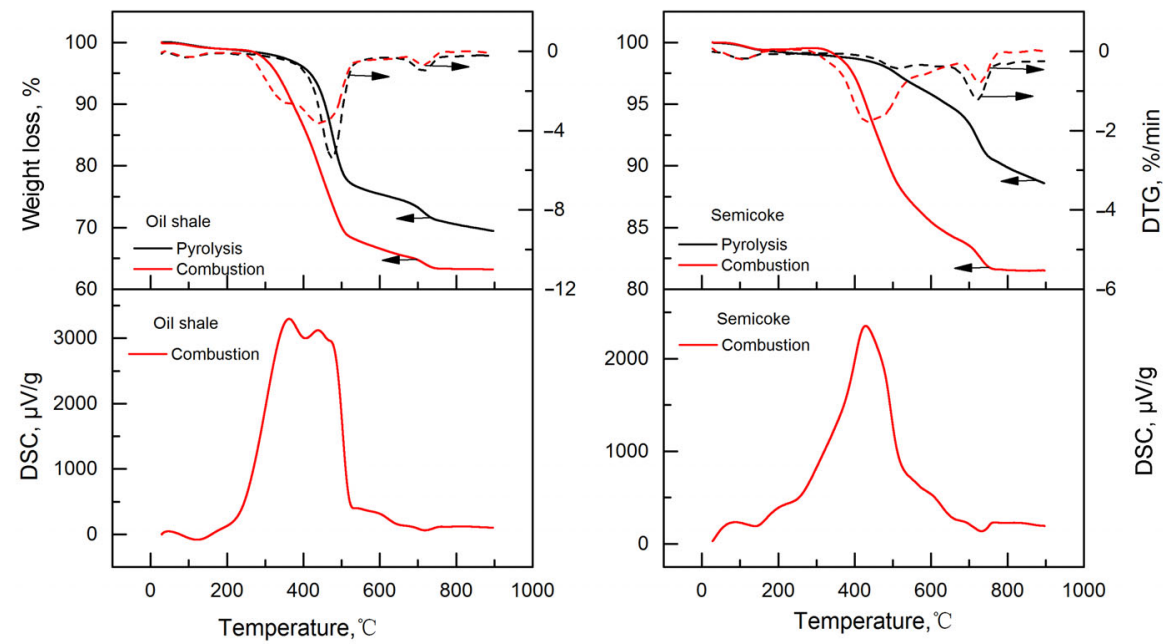

Fig. 2. TGA/DSC analysis of oil shale and semicoke.

Table 2. Characteristic temperatures of combustion of oil shale and semicoke

\begin{tabular}{|l|c|c|c|}
\hline & $T_{\mathrm{i}}{ }^{\circ} \mathrm{C}$ & $T_{\max },{ }^{\circ} \mathrm{C}$ & $T_{\mathrm{b}},{ }^{\circ} \mathrm{C}$ \\
\hline Oil shale & 350 & 438 & 558 \\
Semicoke & 370 & 430 & 601 \\
\hline
\end{tabular}

\subsection{Ignition mechanism}

The ignition mechanism of oil shale and semicoke is further studied using the TGA/DSC analytical results shown in Figure 2. It can be seen from the figure that for the combustion of oil shale, there appear two exothermic peaks after the point of separation of the weight loss curves for pyrolysis and combustion, which means that the ignition mechanism of oil shale is heterohomogeneous [18]. For the combustion of semicoke, only one exothermic peak appears in the DSC curve, indicating the heterogeneous ignition mechanism $[18,19]$. 


\subsection{Drop-tube furnace experiments}

\subsubsection{Carbon conversion and particle burnout}

The carbon conversion and particle burnout from the DTF combustion of oil shale and semicoke are respectively illustrated in Figure 3. The figure shows that the carbon conversion as well as the particle burnout accelerates with increasing combustion temperature in the initial stage and then becomes stable for both oil shale and semicoke. For comparison, the carbon conversion or particle burnout of oil shale becomes steady earlier (at $30 \mathrm{~cm}$ from the injection port) than that of semicoke (at $50 \mathrm{~cm}$ from the injection port), indicating that the oil shale combustion proceeds faster than semicoke's, which is attributed to the higher volatile content of oil shale.

Additionally, the final carbon conversions upong semicoke combustion at all temperatures $\left(87 \%\right.$ at $800{ }^{\circ} \mathrm{C}, 91 \%$ at $900{ }^{\circ} \mathrm{C}, 92 \%$ at $\left.1000{ }^{\circ} \mathrm{C}\right)$ are lower than the corresponding values for oil shale, which is almost the same, $98 \%$, at all temperatures. The particle burnout upon oil shale and semicoke combustions follows the same pattern. The retarded combustion rate of semicoke can be attributed to its higher ash content compared to oil shale's.

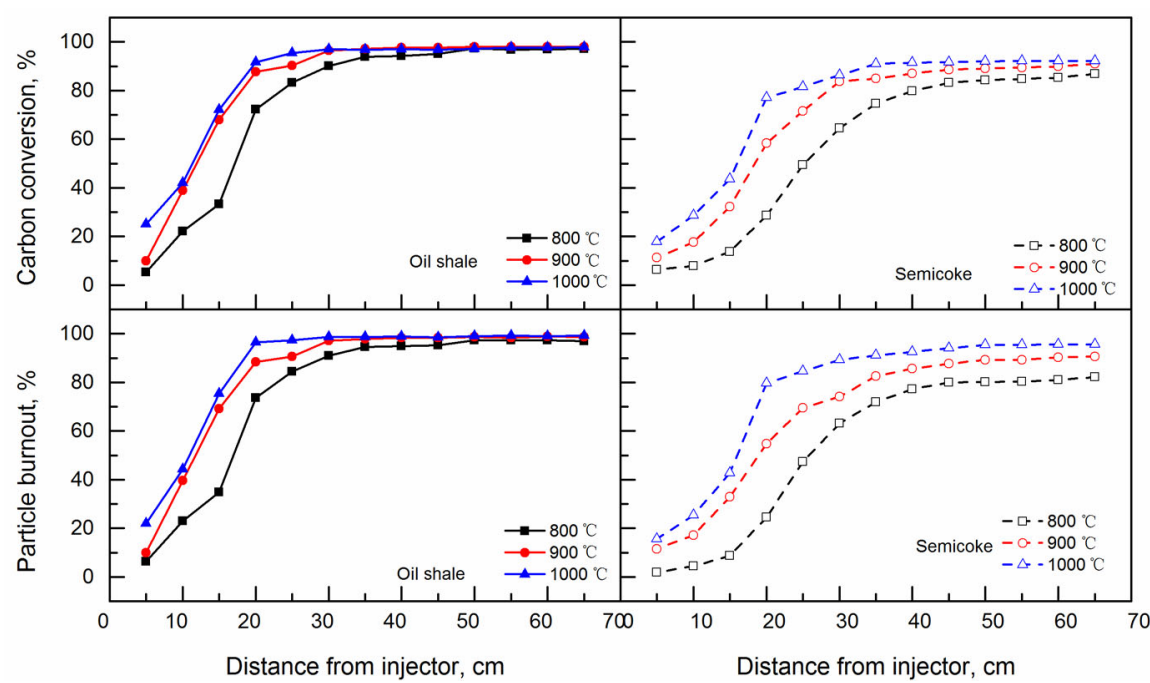

Fig. 3. Carbon conversion and particle burnout upon combustion of oil shale and semicoke in DTF.

\subsubsection{Conversion of $\mathrm{C}, \mathrm{H}, \mathrm{N}$ and $\mathrm{S}$}

The release behavior of carbon $(\mathrm{C})$, hydrogen $(\mathrm{H})$, nitrogen $(\mathrm{N})$ and sulphur (S) upon combustion is also an important indicator of the process, but is seldom discussed in case of combustion of oil shale or semicoke. Herein, the conversions of $\mathrm{C}, \mathrm{H}, \mathrm{N}$ and $\mathrm{S}$ during the combustion of oil shale and 
semicoke with varied particle burnout are studied and the results are shown in Figure 4.

It can be seen from the figure that the carbon conversion proceeds almost simultaneously with the particle burnout for both oil shale and semicoke. By contrast, the conversion of hydrogen is faster and that of nitrogen and sulphur slower. During the combustion of oil shale or semicoke, the release behavior of $\mathrm{C}, \mathrm{H}$ and $\mathrm{S}$ is similar to that in combustion of coal [20-22], but the release behaviour of $\mathrm{N}$ is contrary to that in coal combustion.

In combustion of coal, its nitrogen is mainly composed of pyrrolic-N and pyridinic-N whose stability is lower than that of homoaromatics [23-25]. It determines that the release of nitrogen is faster than that of carbon in the coal semicoke combustion [20]. By contrast, kerogen is mainly composed of aliphatic chains [26], and the nitrogen in oil shale or oil shale semicoke exists similarly mainly in the form of pyrrolic- $\mathrm{N}$ and pyridinic- $\mathrm{N}$ as in coal. For comparison, the straight chain hydrocarbons in oil shale are less stable than the heterocyclic rings in coal, which determines that the release of carbon in combustion of oil shale is faster than that in coal combustion, and thus the release of nitrogen is slower than the liberation of carbon in the oil shale combustion process. The different forms of sulphur in oil shale are mainly organic sulphur, sulphate and sulphide. The organic sulphur and sulphide may be converted to $\mathrm{SO}_{2}$ through combustion, while part of $\mathrm{SO}_{2}$ may not be released and detected because of the capture of $\mathrm{SO}_{2}$ by $\mathrm{CaO}$ in shale ash to form $\mathrm{CaSO}_{4}$, which leads to the slower sulphur conversion than the particle burnout.
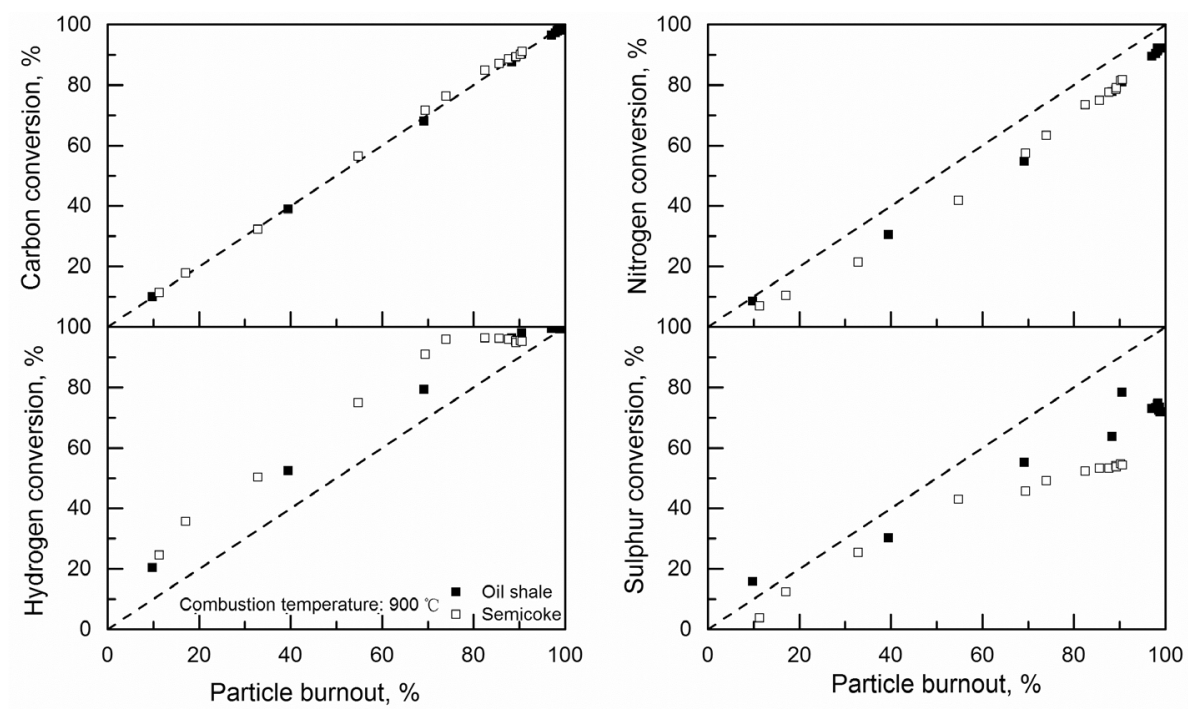

Fig. 4. Conversion of $\mathrm{C}, \mathrm{H}, \mathrm{N}$ and $\mathrm{S}$ during combustion of oil shale and semicoke with varied particle burnout. 


\subsubsection{Emission characteristics}

The concentrations of $\mathrm{CO}, \mathrm{NO}, \mathrm{N}_{2} \mathrm{O}$ and $\mathrm{SO}_{2}$ varying along the axial distance in DTF are shown in Figure 5. The CO concentration reaches a maximum value once the sample is injected into the furnace. With increasing combustion temperature, the maximum concentration of $\mathrm{CO}$ occurs closer to the injection port.
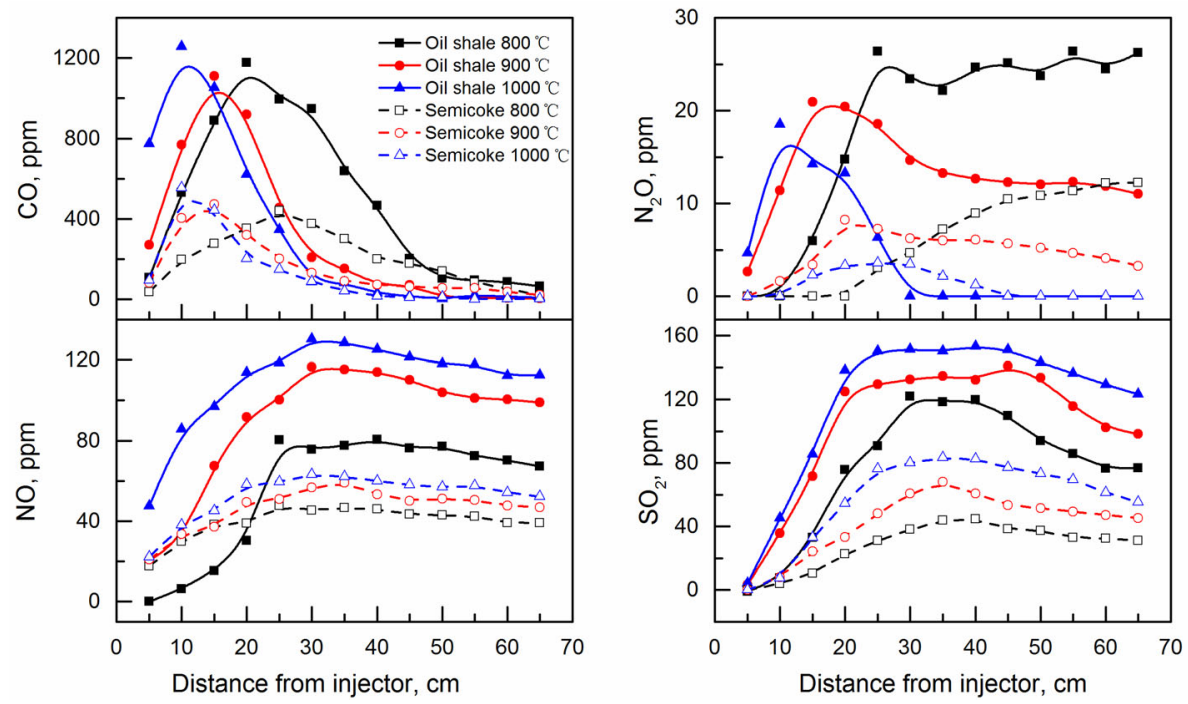

Fig. 5. Emission of $\mathrm{CO}, \mathrm{NO}, \mathrm{N}_{2} \mathrm{O}$ and $\mathrm{SO}_{2}$ during combustion of oil shale and semicoke in DTF.

The concentration of NO increases rapidly in the early stage of combustion, but starts to gradually decrease after it has reached a maximum value. It indicates that the formation of NO proceeds simultaneously with the conversion of NO since NO can be reduced by semicoke in the combustion process [27]. As the combustion temperature increases, the concentration of NO increases accordingly, which agrees with the pattern of coal combustion $[28,29]$. It may be explained by that a higher temperature leads to a higher release of volatiles and the volatile $\mathrm{N}$ is inclined to be oxidized to NO during volatiles combustion [29].

A peak concentration of $\mathrm{N}_{2} \mathrm{O}$ appears in the curves at $900{ }^{\circ} \mathrm{C}$ and $1000{ }^{\circ} \mathrm{C}$ and, interestingly, the emission of $\mathrm{N}_{2} \mathrm{O}$ is zero at the sampling points with a longer distance to the injector at $1000{ }^{\circ} \mathrm{C}$ for both oil shale and semicoke. By contrast, when combusted at $800{ }^{\circ} \mathrm{C}$, the concentration of $\mathrm{N}_{2} \mathrm{O}$ is almost zero in the early stage, and then increases rapidly along the drop tube, becoming finally stable in the rear part of the tube. $\mathrm{N}_{2} \mathrm{O}$ may decompose or be reduced to $\mathrm{N}_{2}$ as reactions (I)-(IV) show [30]. Due to the low content of $\mathrm{H}$ in 
semicoke it is rational that a higher temperature is favorable to the decomposition of $\mathrm{N}_{2} \mathrm{O}$ by reactions (III) and (IV):

$$
\begin{gathered}
\mathrm{N}_{2} \mathrm{O}+\mathrm{H} \rightarrow \mathrm{N}_{2}+\mathrm{OH} \\
\mathrm{N}_{2} \mathrm{O}+\mathrm{OH} \rightarrow \mathrm{N}_{2}+\mathrm{HO}_{2} \\
\mathrm{~N}_{2} \mathrm{O} \rightarrow \mathrm{N}_{2}+\mathrm{O} \\
\mathrm{N}_{2} \mathrm{O}+\mathrm{O} \rightarrow \mathrm{N}_{2}+\mathrm{O}_{2}
\end{gathered}
$$

The emission of $\mathrm{SO}_{2}$ can be enhanced by increasing the combustion temperature, which is in accordance with coal combustion [31]. The concentration of $\mathrm{SO}_{2}$ increases first and then declines along the reaction tube in the combustion of both oil shale and semicoke. The decline of $\mathrm{SO}_{2}$ concentration may be attributed to the reaction of $\mathrm{SO}_{2}$ with $\mathrm{O}_{2}$, and with carbonates in the shale ash, as shown by reactions (V) and (VI):

$$
\begin{gathered}
\mathrm{SO}_{2}+1 / 2 \mathrm{O}_{2} \rightarrow \mathrm{SO}_{3} \\
\mathrm{CaCO}_{3}+\mathrm{SO}_{2}+1 / 2 \mathrm{O}_{2} \rightarrow \mathrm{CaSO}_{4}+\mathrm{CO}_{2}
\end{gathered}
$$

\subsubsection{Combustion kinetics of semicoke}

The kinetics of semicoke combustion is important for designing the furnace and burner system [32], and thus it is studied herein. Based on the first-order reaction model $[33,34]$, the reaction rate can be expressed by Equation (3) [35], and the corresponding coefficients are obtained according to Equations (4)-(6) [35]:

$$
\begin{gathered}
q=k_{\text {diff }}\left(P_{\mathrm{O}_{2}, g}-P_{\mathrm{O}_{2}, s}\right)=k_{s} P_{\mathrm{O}_{2}, s}=k P_{\mathrm{O}_{2}, g}, \\
k_{\text {diff }}=0.00064 \phi\left(T_{g} / 1600\right)^{0.75} / d_{p}, \\
k_{s}=k \cdot k_{\text {diff }} /\left(k_{\text {diff }}-k\right), \\
k_{s}=A_{a} \exp \left(-E_{a} /\left(\mathrm{R} \cdot T_{p}\right)\right),
\end{gathered}
$$

where $q$ is the reaction rate, $\mathrm{g} \cdot \mathrm{cm}^{-2} \cdot \mathrm{s}^{-1} ; k_{\text {diff }}$ is the diffusion rate coefficient, $\mathrm{g} \cdot \mathrm{cm}^{-2} \cdot \mathrm{s}^{-1} \cdot \mathrm{atm}^{-1} ; k$ is the overall reaction rate coefficient and $k_{s}$ is the external surface reaction rate coefficient, $\mathrm{g} \cdot \mathrm{cm}^{-2} \cdot \mathrm{s}^{-1} \cdot \mathrm{atm}^{-1} ; P_{\mathrm{O}_{2}, g}$ and $P_{\mathrm{O}_{2}, s}$ are the partial pressure of oxygen (atm) in the free gas stream and in the particle surface, respectively; $A_{a}$ is the pre-exponential factor, $\mathrm{g} \cdot \mathrm{cm}^{-2} \cdot \mathrm{s}^{-1} \cdot \mathrm{atm}^{-1} ; E_{a}$ is the apparent activation energy, $\mathrm{J} \cdot \mathrm{mol}^{-1} ; T_{P}$ is the particle temperature, $\mathrm{K} ; \mathrm{R}$ is the gas constant, $\mathrm{J} \cdot \mathrm{mol}^{-1} \cdot \mathrm{K}^{-1} ; T_{g}$ is the gas phase temperature and $d_{p}$ is the diameter of solid fuel particles; $\Phi$ is the mechanism factor, which is either valued at 1 if the main product over the 
particle surface is $\mathrm{CO}_{2}$ or at 2 for $\mathrm{CO}$. Herein, the main product is $\mathrm{CO}_{2}$, and thus the reaction rate can be written as Equation (7):

$$
q=\frac{\rho_{p} d_{p}}{6 t}\left(1-A_{0}\right)\left(B_{2}-B_{1}\right),
$$

where $\rho_{p}$ is the density of semicoke particles; $A_{0}$ is the ash content of semicoke; $t$ is the residence time of semicoke in the drop-tube furnace, s; $B_{2}$ and $B_{1}$ are particle burnouts at different sampling positions. The residence time is calculated on the assumption that the gas flow is laminar and the particle velocity is same as the gas flow velocity.

The particle size distribution of semicoke is analyzed by a laser particle size analyzer and the mean particle size is $30 \mu \mathrm{m}$. The particle size of the residue sample probed at $65 \mathrm{~cm}$ from the feed injection port after combustion of semicoke is also measured and the mean particle size is $28 \mu \mathrm{m}$. This means that the particle size is generally constant during the semicoke combustion process. The density of semicoke is measured to be $2400 \mathrm{~kg} / \mathrm{m}^{3}$ by the pycnometer method, and it is assumed to be constant before and after combustion due to the high ash content of semicoke.

Considering that the particle temperature is different from the gas phase temperature, the particle temperature is calculated by Equation (8) [35]:

$$
q H_{c}-2 \lambda / d_{p}\left(T_{p}-T_{g}\right)-\varepsilon \sigma\left(T_{p}^{4}-T_{w}^{4}\right)=0,
$$

where $\lambda$ is the thermal conductivity of gas, $7.63 \times 10^{-4} \mathrm{~W} \cdot \mathrm{cm}^{-1} \cdot \mathrm{K}^{-1} ; \varepsilon$ is the emissivity and is taken to be 1 [35]; $\sigma$ is the Stefan-Boltzmann constant, $5.67 \times 10^{-12} \mathrm{~W} \cdot \mathrm{cm}^{-2} \cdot \mathrm{K}^{-4} ; T_{p}, T_{g}$ and $T_{w}$ are the temperatures of the particle, the free gas stream and the wall of DTF, $\mathrm{K}$, respectively; $H_{\mathrm{c}}$ is the heat released per gram of carbon burnt, $9625.5 \mathrm{~J} / \mathrm{g}$.

From the above equations, the values of $k_{\mathrm{s}}$ varying with a series of $T_{\mathrm{p}}$ can be obtained. According to Equation (6), $\ln k_{\mathrm{s}}$ has a linear correlation with $1 / T_{\mathrm{p}}$ as shown in Figure 6 . The pre-exponential factor $A_{\mathrm{a}}$ $\left(26.3 \mathrm{~g} \cdot \mathrm{cm}^{-2} \cdot \mathrm{s}^{-1} \cdot \mathrm{atm}^{-1}\right)$ and the apparent activation energy $E_{\mathrm{a}}(65.8 \mathrm{~kJ} / \mathrm{mol})$ can be obtained from the slope and the intercept of the line, respectively. Equation (6) with known parameters is therefore given in Equation (9):

$$
k_{s}=26.3 \exp \left(\frac{-65800}{R \cdot T_{p}}\right) \text {. }
$$

The combustion activation energy of semicoke of coal (brown coal, bituminous coal and anthracite) generally varies in the range of $51-142 \mathrm{~kJ} / \mathrm{mol}[33,34,36-39]$, which is attributed to the changes of volatile contents of coal semicoke. So, in the current work, the activation energy of $65.8 \mathrm{~kJ} / \mathrm{mol}$ for oil shale semicoke combustion is in the same range. 


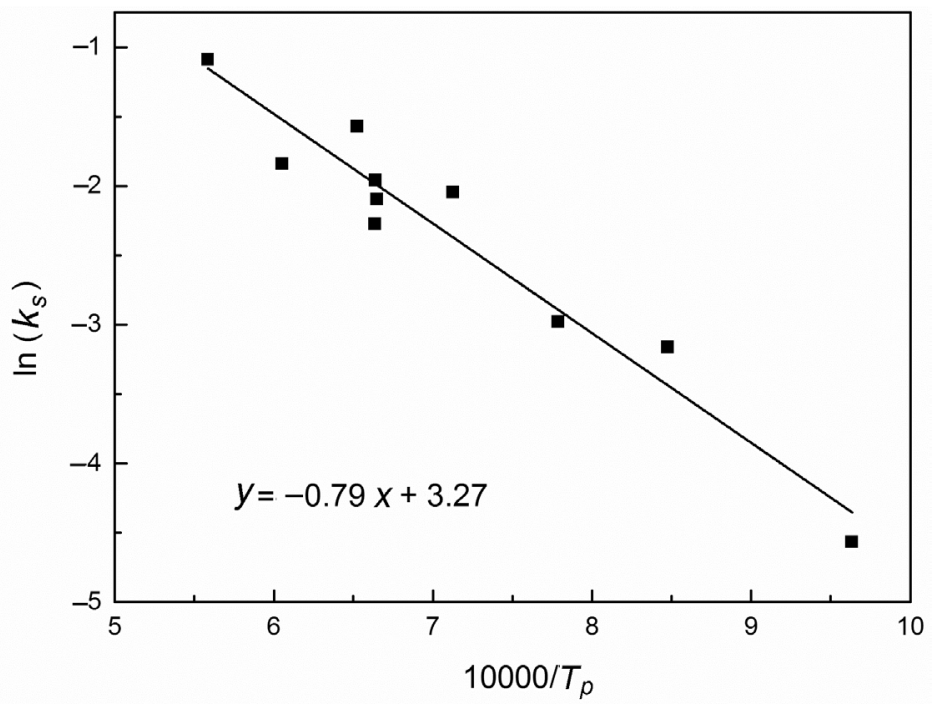

Fig. 6. Linear correlation between the value of $\ln k_{s}$ and $1 / T_{p}$.

Goldfarb et al. [14] also investigated the oxidation kinetics of oil shale semicoke, but used the isothermal method with TGA. For comparison, the $E_{\mathrm{a}}$ obtained through the TGA method in the work of Goldfarb et al. is higher than that from the DTF process obtained in this work. It can be explained by the fact that there exists a higher resistance of air to diffusion in the particles bed in the crucible, which increases the apparent activation energy by the TGA method.

\section{Conclusions}

The combustion characteristics of Huadian oil shale and its semicoke are studied using a thermobalance and a drop-tube furnace. It is found that the ignition mechanism of oil shale and semicoke is hetero-homogeneous and heterogeneous, respectively. In drop-tube furnace experiments on combustion of oil shale and semicoke, the carbon conversion proceeds almost simultaneously with the particle burnout, while the hydrogen conversion is faster and that of nitrogen and sulphur is slower than the particle burnout. A higher combustion temperature favors the emission of $\mathrm{NO}$ and $\mathrm{SO}_{2}$, whereas, contrarily, the emission of $\mathrm{N}_{2} \mathrm{O}$ is zero at a high combustion temperature, $1000{ }^{\circ} \mathrm{C}$, for both oil shale and semicoke. The kinetic behavior of semicoke combustion is analyzed through drop-tube furnace experiments based on the first-order reaction model, and the equation of the reaction rate coefficient with known pre-exponential factor $A_{\mathrm{a}}\left(26.3 \mathrm{~g} \cdot \mathrm{cm}^{-2} \cdot \mathrm{s}^{-1} \cdot \mathrm{atm}^{-1}\right)$ and apparent activation energy $E_{\mathrm{a}}(65.8 \mathrm{~kJ} / \mathrm{mol})$ is obtained. 


\section{Acknowledgments}

The work was supported by the "Transformational Technologies for Clean Energy and Demonstration" Strategic Priority Research Program of the Chinese Academy of Sciences, Grant No. XDA 21040400.

\section{REFERENCES}

1. Na, J. G., Im, C. H., Chung, S. H., Lee, K. B. Effect of oil shale retorting temperature on shale oil yield and properties. Fuel, 2012, 95, 131-135.

2. Wang, S., Jiang, X., Han, X., Tong, J. Investigation of Chinese oil shale resources comprehensive utilization performance. Energy, 2012, 42(1), 224-232.

3. Qian, J., Yin, L. Oil Shale - Petroleum Alternative. China Petrochemical Press, 2008 (in Chinese).

4. Yefimov, V., Doilov, S., Pulemyotov, I. Development of ecologically acceptable technology for processing large particle kukersite in vertical retorts. Oil Shale, 1997, 14(1), 77-83.

5. Kahru, A., Põllumaa, L. Environmental hazard of the waste streams of Estonian oil shale industry: an ecotoxicological review. Oil Shale, 2006, 23(1), 53-93.

6. Külaots, I., Goldfarb, J. L., Suuberg, E. M. Characterization of Chinese, American and Estonian oil shale semicokes and their sorptive potential. Fuel, 2010, 89(11), 3300-3306.

7. Trikkel, A., Kuusik, R., Martins, A., Pihu, T., Stencel, J. M. Utilization of Estonian oil shale semicoke. Fuel Process. Technol., 2008, 89(8), 756-763.

8. Wang, J., Lu, X., Yao, J., Lin, W., Du, L. Total distribution and liquid composition of products from coal topping process in a downer reactor. The Chinese Journal of Process Engineering, 2005, 5(3), 241-245 (in Chinese).

9. Aarna, I. The 3rd International Oil Shale Symposium in Tallinn. Oil Shale, 2009, 26(3), 349-357.

10. Shi, W., Wang, Z., Song, W., Li, S., Li, X. Pyrolysis of Huadian oil shale under catalysis of shale ash. J. Anal. Appl. Pyrol., 2017, 123, 160-164.

11. Lai, D., Zhang, G., Xu, G. Characterization of oil shale pyrolysis by solid heat carrier in moving bed with internals. Fuel Process. Technol., 2017, 158, 191-198.

12. Lai, D., Shi, Y., Geng, S., Chen, Z., Gao, S., Zhan, J., Xu, G. Secondary reactions in oil shale pyrolysis by solid heat carrier in a moving bed with internals. Fuel, 2016, 173, 138-145.

13. Qin, H., Wang, W., Liu, H., Zhang, L., Wang, Q., Shi, C. Thermal behavior research for co-combustion of furfural residue and oil shale semi-coke. Appl. Therm. Eng., 2017, 120, 19-25.

14. Goldfarb, J. L., D’Amico, A., Culin, C., Suuberg, E. M., Külaots, I. Oxidation kinetics of oil shale semicokes: reactivity as a function of pyrolysis temperature and shale origin. Energ. Fuel., 2013, 27(2), 666-672.

15. Ma, B., Li, X., Xu, L., Wang, K., Wang, X. Investigation on catalyzed combustion of high ash coal by thermogravimetric analysis. Thermochim. Acta, 2006, 445(1), 19-22. 
16. Artos, V., Scaroni, A. W. T.g.a. and drop-tube reactor studies of the combustion of coal blends. Fuel, 1993, 72(7), 927-933.

17. Mayoral, M. C., Izquierdo, M. T., Andrés, J. M., Rubio, B. Different approaches to proximate analysis by thermogravimetry analysis. Thermochim. Acta, 2001, 370(1-2), 91-97.

18. Arenillas, A., Rubiera, F., Arias, B., Pis, J. J., Faúndez, J. M., Gordon, A. L., Garcia, X. A. A TG/DTA study on the effect of coal blending on ignition behaviour. J. Therm. Anal. Calorim., 2004, 76(2), 603-614.

19. Chen, Y., Mori, S., Pan, W. P. Studying the mechanism of ignition of coal particles by TG-DTA. Thermochim. Acta, 1996, 275(1), 149-158.

20. Baxter, L. L., Mitchell, R. E., Fletcher, T. H., Hurt, R. H. Nitrogen release during coal combustion. Energ. Fuel., 1996, 10(1), 188-196.

21. Wang, G., Zander, R., Costa, M. Oxy-fuel combustion characteristics of pulverized-coal in a drop tube furnace. Fuel, 2014, 115, 452-460.

22. Murphy, J. J., Shaddix, C. R. Combustion kinetics of coal chars in oxygenenriched environments. Combust. Flame, 2006, 144(4), 710-729.

23. Bartle, K. D., Perry, D. L., Wallace, S. The functionality of nitrogen in coal and derived liquids: An XPS study. Fuel Process. Technol., 1987, 15, 351-361.

24. Nelson, P. F., Buckley, A. N., Kelly, M. D. Functional forms of nitrogen in coals and the release of coal nitrogen as $\mathrm{NO}_{\mathrm{x}}$ precursors $\left(\mathrm{HCN}\right.$ and $\left.\mathrm{NH}_{3}\right)$. Twenty-fourth Symposium (International) on Combustion, July 5-10, University of Sydney, Australia. The Combustion Institute, Pittsburgh, PA, 1992, 1259-1267.

25. Wallace, S., Bartle, K. D., Perry, D. L. Quantification of nitrogen functional groups in coal and coal derived products. Fuel, 1989, 68(11), 1450-1455.

26. Lille, Ü., Heinmaa, I., Pehk, T. Molecular model of Estonian kukersite kerogen evaluated by ${ }^{13} \mathrm{C}$ MAS NMR spectra. Fuel, 2003, 82(7), 799-804.

27. Aarna, I., Suuberg, E. M. The role of carbon monoxide in the NO-carbon reaction. Energ. Fuel., 1999, 13(6), 1145-1153.

28. Pels, J. R., Wójtowicz, M. A., Moulijn, J. A. Rank dependence of $\mathrm{N}_{2} \mathrm{O}$ emission in fluidized-bed combustion of coal. Fuel, 1993, 72(3), 373-379.

29. Zhao, J., Grace, J. R., Lim, J. C., Brereton, C. M. H., Legros, R. Influence of operating parameters on $\mathrm{NO}_{\mathrm{x}}$ emissions from a circulating fluidized bed combustor. Fuel, 1994, 73(10), 1650-1657.

30. Li, S., Xu, M., Jia, L., Tan, L., Lu, Q. Influence of operating parameters on $\mathrm{N}_{2} \mathrm{O}$ emission in $\mathrm{O}_{2} / \mathrm{CO}_{2}$ combustion with high oxygen concentration in circulating fluidized bed. Appl. Energ., 2016, 173, 197-209.

31. Chen, L., Bhattacharya, S. Sulfur emission from Victorian brown coal under pyrolysis, oxy-fuel combustion and gasification conditions. Environ. Sci. Technol., 2013, 47(3), 1729-1734.

32. Hurt, R. H., Haynes, B. S. On the origin of power-law kinetics in carbon oxidation. P. Combust. Inst., 2005, 30(2), 2161-2168.

33. Karlström, O., Brink, A., Hupa, M., Tognotti, L. Multivariable optimization of reaction order and kinetic parameters for high temperature oxidation of 10 bituminous coal chars. Combust. Flame, 2011, 158(10), 2056-2063.

34. Ballester, J., Jiménez, S. Kinetic parameters for the oxidation of pulverised coal as measured from drop tube tests. Combust. Flame, 2005, 142(3), 210-222.

35. Field, M. A. Rate of combustion of size-graded fractions of char from a lowrank coal between $1200^{\circ} \mathrm{K}$ and $2000^{\circ} \mathrm{K}$. Combust. Flame, 1969, 13(3), $237-252$ 
36. Smith, I. W. The combustion rates of coal chars: A review. Nineteenth Symposium (International) on Combustion, 8-13 August 1982, Technion-Israel Institute of Technology, Haifa, Israel. The Combustion Institute, Philadelphia, 1982, 1045-1065.

37. Smith, I. W. Kinetics of combustion of size-graded pulverized fuels in the temperature range $1200-2270^{\circ}$ K. Combust. Flame, 1971, 17(3), 303-314.

38. Smith, I. W. The kinetics of combustion of pulverized semi-anthracite in the temperature range $1400-2200^{\circ} \mathrm{K}$. Combust. Flame, 1971, 17(3), 421-428.

39. Mitchell, R. E., Hurt, R. H., Baxter, L. L., Hardesty, D. R. Compilation of Sandia Coal Char Combustion Data and Kinetic Analyses. Milestone Report. Sandia Technical Report, SAND92-8208. Sandia National Labs, Livermore, CA, 1992.

Presented by Ma Yue and I. Külaots

Received November 15, 2018 